\title{
HUBUNGAN PENYEDIAAN AIR BERSIH DAN JAMBAN KELUARGA DENGAN KEJADIAN DIARE PADA BALITA DI DESA MALA KECAMATAN MANGANITU TAHUN 2015
}

\author{
Dismo Katiandagho ${ }^{1}$, Darwel ${ }^{2}$

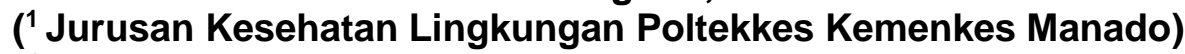 \\ ( ${ }^{2}$ Jurusan Kesehatan Lingkungan Poltekkes Kemenkes Padang)
}

\begin{abstract}
Data from the Health Office of the Sangihe Regency up to June 2014, there were 708 diarrhea cases, the most cases were at age> 5 years totaling 430 cases; the highest cases were in the working area of the Manganitu Health Center as many as 115 cases, and the village with the most diarrhea cases was Mala Village as many as 73 cases of diarrhea suffered by toddlers. The research objective is to determine the relationship between the provision of clean water and family latrines with the incidence of diarrhea in Mala Village, Manganitu District. This type of research is an observational analytic study with a cross sectional study design. The sample size in this study was the entire population of 73 toddlers being sampled. The results of bivariate data processing and analysis using the test chi square showed that there was a significant relationship between the provision of clean water facilities and the incidence of diarrhea in infants and there was a significant relationship between the provision of family latrines with the incidence of diarrhea in infants. The conclusion is that there is a significant relationship between the provision of clean water and the provision of family toilets with the occurrence of diarrhea in Mala Village, Manganitu District. Suggestions For people who do not have clean water facilities and family latrines to make or build clean water facilities and family latrines and the need for the role and support of health workers in the prevention of diarrheal diseases transmitted through the environment, officers always make observations and supervision to maintain the spread of disease based environment such as diarrhea.
\end{abstract}

Keywords: provision of clean water facilities; family latrines; diarrhea in toddlers

\section{PENDAHULUAN}

Diare adalah buang besar dengan frekuensi yang yang tidak normal (meningkat) dan konsistensi tinja yang lembek atau cair. Menurut data WHO pada tahun $2000-2003$ diare merupakan penyebab kematian nomor tiga di dunia pada anak di bawah umur lima tahun, dengan Proportional Mortality Rate (PMR) $17 \%$ setelah kematian neonatal $37 \%$ dan pneumonia 19,5\%. Faktor risiko yang sangat berpengaruh untuk terjadinya diare pada balita yaitu kesehatan lingkungan (penggunaan sarana air bersih, jamban keluarga, pembuangan sampah, pembuangan air limbah) dan perilaku hidup sehat dalam keluarga ${ }^{1}$.

Berdasarkan data dari Dinas Kesehatan Kabupaten Kepulauan Sangihe sampai pada bulan Juni 2014, terdapat 708 kasus diare, kasus tertinggi terdapat pada usia > 5 tahun sebanyak 430 kasus, kasus tertinggi terdapat di wilayah kerja Puskesmas Manganitu sebanyak 115 kasus. Desa dengan kasus diare terbanyak yaitu Desa Mala sebanyak 73 kasus diare yang diderita oleh balita (Dinkes Sangihe, 2014) ${ }^{2}$. Sesuai dengan hasil survey 
pendahuluan di beberapa tempat/Desa yang terdapat di wilayah kerja Puskesmas Manganitu khususnya di Desa Mala, dimana terdapat masyarakat yang menggunakan air sumur gali yang letaknya berdekatan dengan kandang ternak, bahkan terletak dengan tempat pembuangan sampah, dan hasil pengamatan untuk konstruksi sumur gali, terdapat beberapa sumur yang tidak mempunyai dinding sumur, sehingga tidak menutup kemungkinan air yang dikonsumsi oleh beberapa rumah tangga tercemar oleh bahan pencemar dari kandang ternak maupun dari tempat pembuangan sampah.

Berdasarkan latar belakang masalah tersebut, maka penulis tertarik untuk melakukan penelitian dengan topik hubungan penyediaan air bersih dan jamban keluarga dengan kejadian diare pada balita di Mala Kecamatan Manganitu. Berdasarkan latar belakang masalah di atas, maka rumusan masalah dalam penelitian ini yaitu apakah ada hubungan penyediaan air bersih dan jamban keluarga dengan kejadian diare pada balita di Desa Mala Kecamatan Manganitu. Tujuan penelitian ini yairu untuk mengetahui hubungan hubungan antara penyediaan air bersih dan jamban keluarga dengan kejadian diare pada balita di Desa Mala Kecamatan Manganitu.

\section{METODE PENELITIAN}

Jenis penelitian ini merupakan studi observasional analitik dengan rancangan cross sectional study, populasi adalah seluruh balita yang ada di Desa Mala Kecamatan Manganitu sebanyak 73 balita, dengan sampel seluruh populasi yaitu 73 orang balita (total populasi). Instrument yang digunakan dalam penelitian ini yaitu kuesioner dan lembar observasi. Analisis data dilakukan secara univariat dan analisis bivariat dilakukan untuk mengetahui hubungan penyediaan sarana air bersih (SAB) dan penyediaan jamban keluarga dengan kejadian diare, analisis data menggunakan uji Chi square dengan pengujian hipotesis nol $(\mathrm{Ho})$ atau hipotesis yang akan ditolak. Interpretasi : Ho ditolak bila $p$ $<$ a $(0,05)$. Analisis data dilakukan dengan menggunakan komputer program SPSS (Statistical Product and Service Solutions) versi 20.

\section{HASIL PENELITIAN}

1. Hasil Analisis Univariat

a. Hasil analisis univariat karakteristik responden

1) Distribusi Umur Balita

Distribusi umur balita di Desa Mala Kecamatan Manganitu paling banyak adalah balita dengan umur 3-4 tahun sebanyak 37 orang (50,7\%) dan sisanya adalah balita dengan umur 1-2 tahun sebanyak 36 orang $(49,3 \%)$.

2) Distribusi Jenis Kelamin Balita

Jenis kelamin balita paling banyak adalah perempuan sebanyak 41 orang $(56,2 \%)$ dan sisanya adalah laki-laki sebanyak 32 orang $(43,8 \%)$. 
b. Hasil analisis univariat penyediaan sarana air bersih dan penyediaan jamban keluarga

1) Distribusi responden berdasarkan kepemilikan sarana penyediaan air bersih (SAB) di Desa Mala.

Hasil pengolahan data untuk responden yang memiliki sarana air bersih di Desa Mala Kecamatan Manganitu dapat dilihat pada gambar 1, di bawah ini :

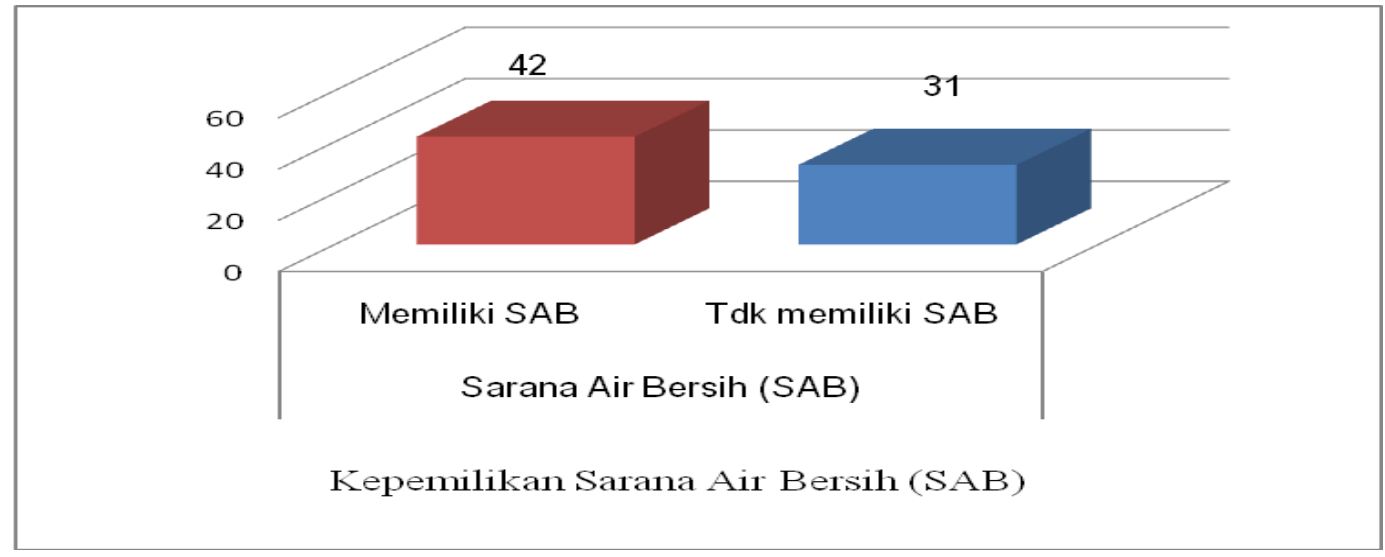

Gambar 1. Distribusi Responden Berdasarkan Kepemilikan Sarana Air Bersih (SAB) di Desa Mala Kecamatan Manganitu Tahun 2015

Gambar 2 menjelaskan bahwa responden yang memiliki sarana air bersih sebanyak 42 responden $(57,5 \%)$ dan responden yang tidak memiliki sarana air bersih sebanyak 31 responden (42,5\%). Jenis sarana air bersih yang dimiliki oleh responden di Desa Mala Kecamatan Manganitu tahun 2015, paling banyak adalah air sumur gali (SGL) sebanyak 30 responden $(41,1)$, PDAM digunakan oleh 12 orang responden $(16,4 \%)$ dan responden yang tidak memiliki sarana air bersih sebanyak 31 responden (42,5\%). Untuk lebih jelasnya dapat dilihat pada gambar 2 berikut ini :

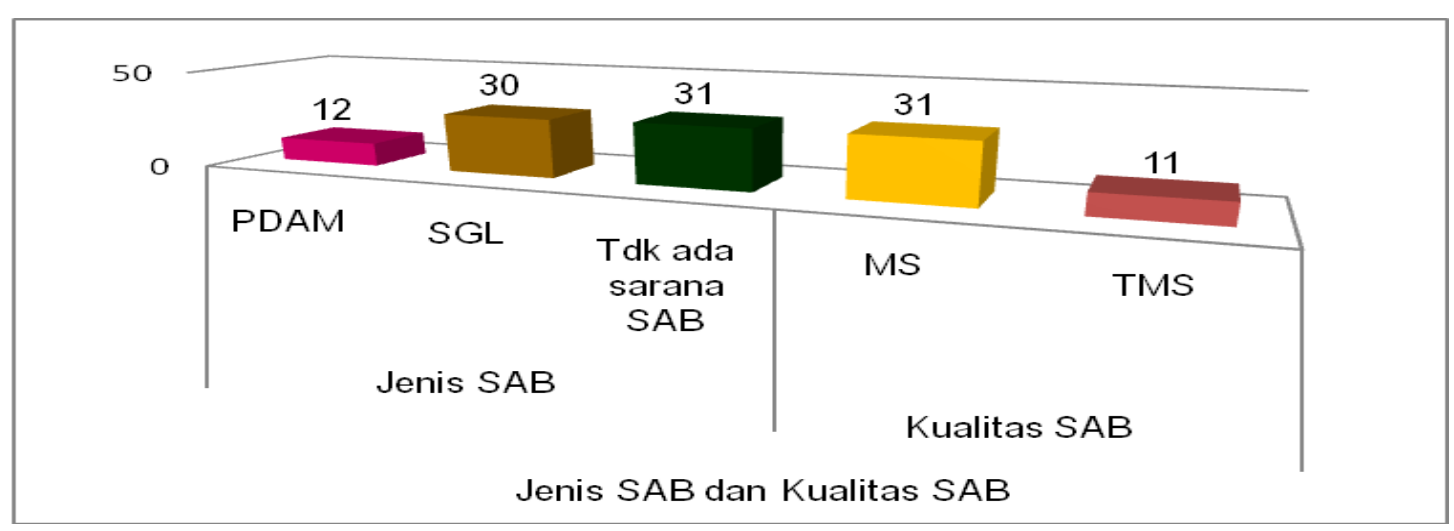

Gambar 2. Distribusi Responden Berdasarkan Jenis Sarana dan Kualitas Sarana Air Bersih di Desa Mala Kecamatan Manganitu Tahun 2015 
Gambar 2 menjelaskan bahwa sarana air bersih yang digunakan oleh responden, dengan kualitas sarana air bersih yang memenuhi syarat sebanyak 31 sarana $(42,5 \%)$ dan sarana air bersih yang tidak memenuhi syarat sebanyak 11 sarana $(15,1 \%)$, responden yang tidak memiliki SAB sebanyak 31 responden $(42,5 \%)$. Resoponden yang tidak memiliki sarana menggunakan sarana air bersih menumpang pada tetangga dan menanfaatkan SAB umum dengan sumber air dari PDAM yang disediakan oleh pemerintah Desa Mala. Sarana air bersih yang dimiliki oleh 42 responden $(57,5 \%)$ dengan jenis sarana yaitu PDAM dan SGL serta responden yang tidak memiliki sarana air bersih memanfaatkan SAB umum sebanyak 13 responden $(17,8 \%)$ dan responden menumpang pada tetangga sebanyak 18 responden (24,6\%). Untuk lebih jelasnya pemanfaatan sarana air bersih oleh responden dan kualitas fisik dapat dilihat pada gambar 3, di bawah ini :

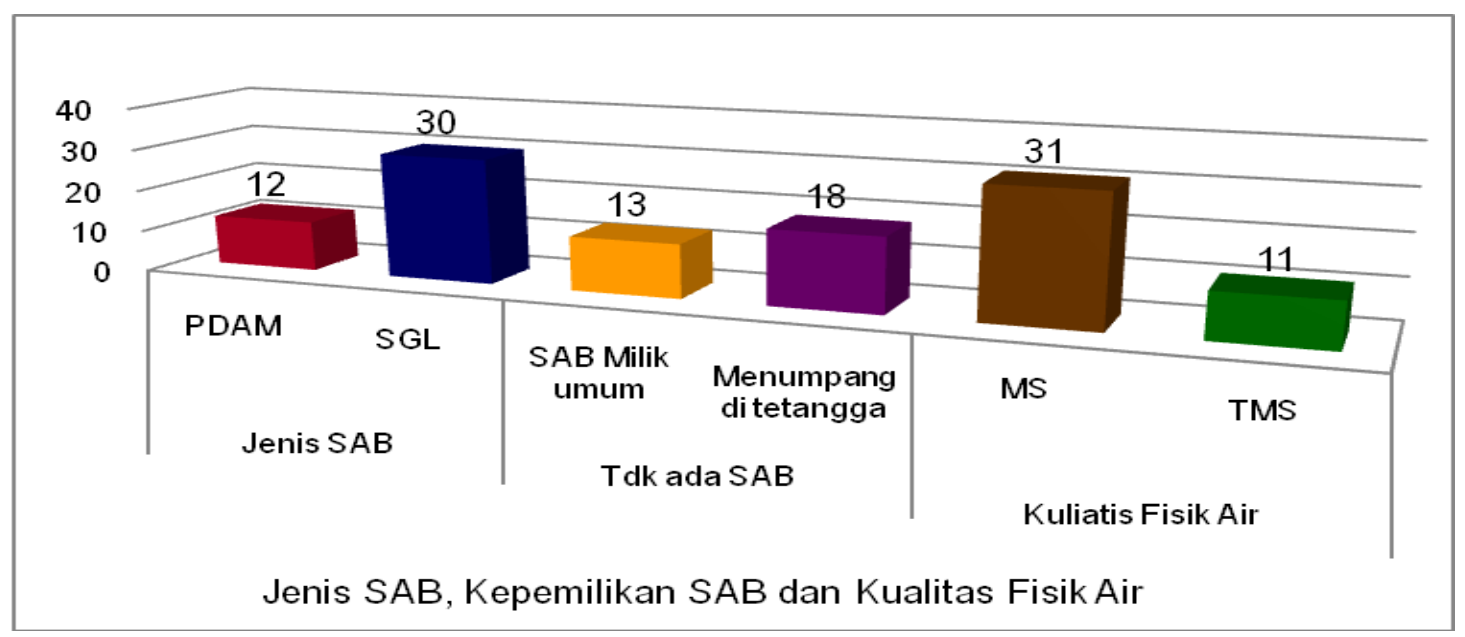

Gambar 3. Distribusi Responden Berdasarkan Jenis SAB, Kepemilikan dan Penggunaan Sarana serta Kualitas Fisik Air Bersih di Desa Mala Kecamatan Manganitu Tahun 2015

Gambar 3 menjelaskan bahwa kualitas fisik air yang digunakan oleh responden dengan kaulitas fisik air bersih yang memenuhi syarat sebanyak $53(72,6 \%)$ dengan kondisi fisik air yaitu tidak berasa, tidak berwarna dan tidak berbau dan kondisi fisik air bersih yang tidak memenuhi syarat sebanyak 20 (27,4\%), dengan kualitas fisik air yaitu berasa, berwarna (air berwarna keruh) dan berbau. Responden yang tidak memiliki sarana air bersih sebanyak 31 responden (42,5\%) menumpang pada tetangga dan menafaatkan sarana milik umum.

2) Distribusi sarana penyediaan jamban keluarga di Desa Mala

Sarana jamban keluarga yang dimiliki oleh responden sebanyak 48 responden memiliki jamban $(65,8 \%)$ dan responden yang tidak memiliki jamban keluarga 
sebanyak 25 responden (34,2\%). Untuk lebih jelanya kepemilikan sarana jamban keluarga dapat dilihat pada gambar 4 di bawah ini :

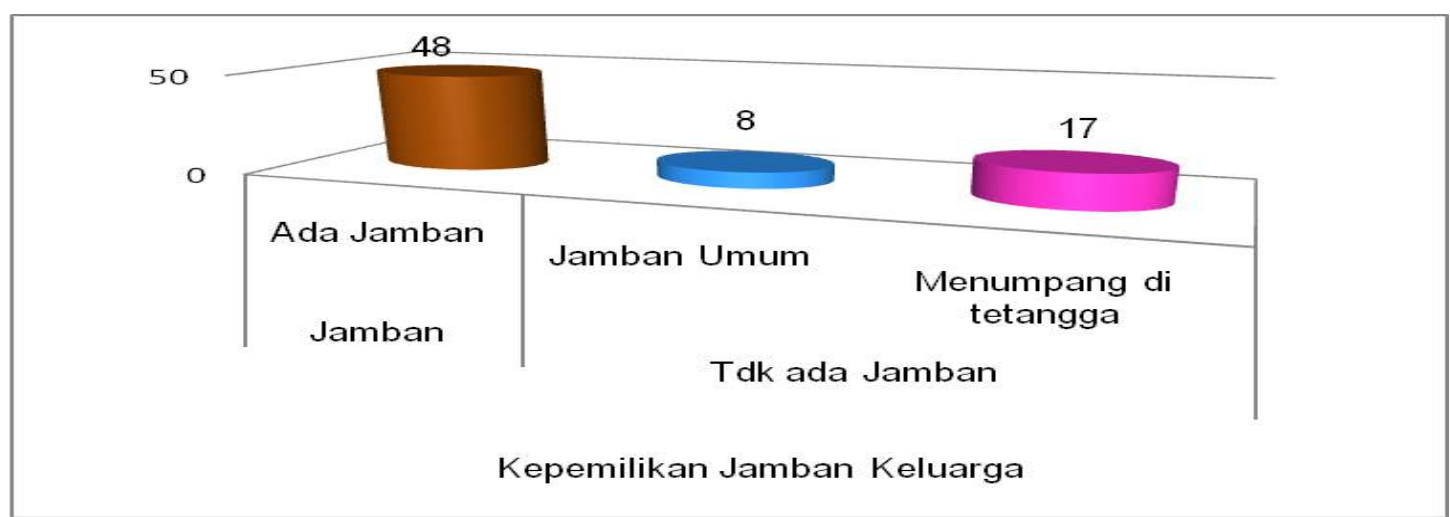

Gambar 4. Distribusi Responden Berdasarkan Kepemilikan dan Penggunaan Sarana Jamban Keluarga di Desa Mala Kecamatan Manganitu Tahun 2015

3) Distribusi kejadian diare di Desa Mala

Hasil pengolahan data untuk balita yang menjadi responden dan menderita diare sebanyak 46 orang balita $(63,1 \%)$ dan balita yang tidak menderita diare sebanyak 27 orang $(36,9 \%)$. Distribusi balita berdasarkan kejadian diare dapat dilihat dapat dilihat pada gambar 5 di bawah ini :

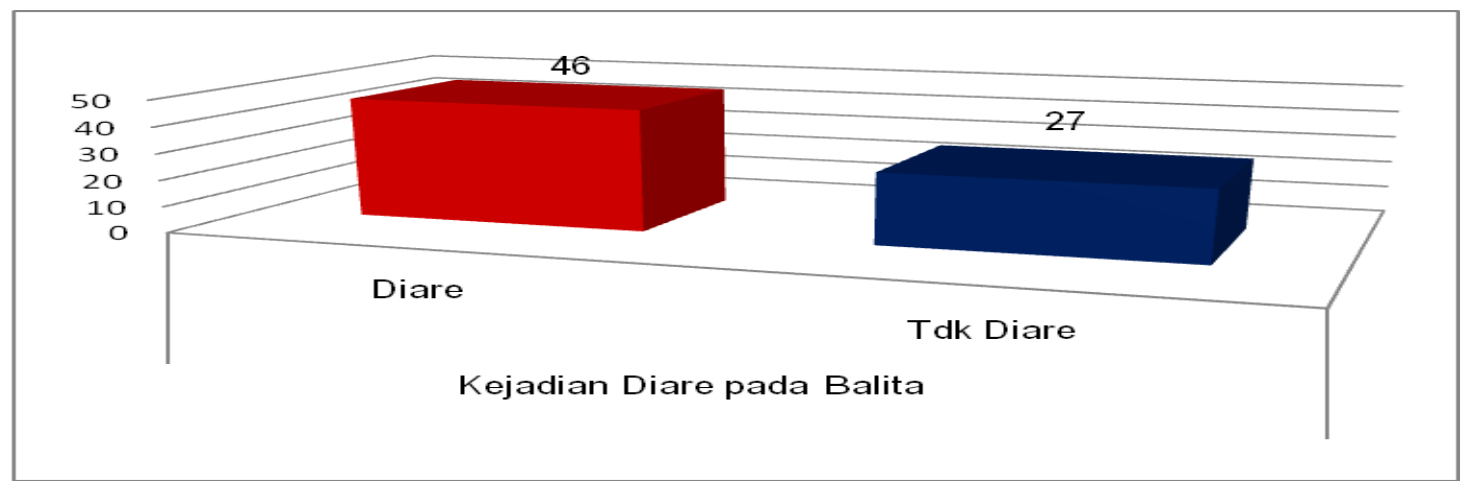

Gambar 5. Distribusi Balita Berdasarakan Kejadian Diare di Desa Mala Kecamatan Manganitu Tahun 2015

c. Hasil analisis univariat variabel penelitian

Hasil analisis secara univariat untuk hubungan penyediaan air bersih dan penyediaan jamban keluarga dengan kejadian diare pada balita di Desa Mala Kecamatan Manganitu, dapat diuraikan sebagai berikut :

1) Penyediaan Sarana Air Bersih (SAB) dengan Kejadian Diare pada Balita Hasil analisis univariat untuk penyediaan sarana air bersih di Desa Mala dapat dilihat pada tabel 1 di bawah ini : 
Tabel 1. Hasil Analisis Univariat Penyediaan Sarana Air Bersih dengan Kejadian Diare Pada Balita di Desa Mala Kecamatan Manganitu Tahun 2015

\begin{tabular}{|c|c|c|c|c|c|c|}
\hline \multirow{2}{*}{$\begin{array}{c}\text { Penyediaan Sara Air } \\
\text { Bersih (SAB) }\end{array}$} & \multicolumn{4}{|c|}{ Kejadian Diare Pada Balita } & \multirow{2}{*}{$\mathbf{N}$} & \multirow{2}{*}{$\%$} \\
\hline & Diare & $\%$ & Tdk Diare & $\%$ & & \\
\hline Tidak ada SAB & 26 & 35.6 & 5 & 6.8 & 31 & 42.5 \\
\hline Ada SAB & 20 & 27.4 & 22 & 30.1 & 42 & 57.5 \\
\hline Total & 46 & 63 & 27 & 36.9 & 73 & 100 \\
\hline
\end{tabular}

Tabel 1 menjelaskan bahwa penyediaan sarana air bersih oleh responden paling banyak adalah responden memiliki sarana air bersih sebanyak 42 responden $(57,5 \%)$ dan responden yang tidak memiliki sarana air bersih sebanyak 31 responden $(42,5 \%)$. Responden yang tidak memiliki sarana air bersih dan balita menderita diare sebanyak 26 orang balita $(35,6 \%)$, balita yang tidak menderita diare sebenyak 5 orang balita $(6,8 \%)$. Responden yang memiliki sarana air bersih dan balita menderita diare sebanyak 20 orang balita $(27,4 \%)$ dan balita yang tidak menderita diare sebanyak 22 orang balita $(30,1 \%)$. Kualitas sarana air bersih dengan kejadian diare pada balita dapat dilihat pada tabel 2 berikut ini :

Tabel 2. Hasil Analisis Univariat Kualitas Sarana Air Bersih dengan Kejadian Diare Pada Balita di Desa Mala Kecamatan Manganitu Tahun 2015

\begin{tabular}{|c|c|c|c|c|c|c|}
\hline \multirow{2}{*}{$\begin{array}{c}\text { Kualitas Sarana Air } \\
\text { Bersih (SAB) }\end{array}$} & \multicolumn{4}{|c|}{ Kejadian Diare Pada Balita } & \multirow{2}{*}{$\mathbf{N}$} & \multirow{2}{*}{$\%$} \\
\hline & Diare & $\%$ & Tdk Diare & $\%$ & & \\
\hline TMS & 7 & 9.6 & 4 & 5.5 & 11 & 15 \\
\hline MS & 12 & 16.4 & 19 & 26 & 31 & 42.5 \\
\hline Tdk ada SAB & 27 & 37 & 4 & 5.5 & 31 & 42.5 \\
\hline Total & 46 & 63 & 27 & 37 & 73 & 100 \\
\hline
\end{tabular}

Tabel 2 menjelaskan bahwa kualitas sarana air bersih yang tidak memenuhi syarat sebanyak 11 SAB (15\%) dan balita yang menderita diare sebanyak 7 orang balita $(9,6 \%)$ dan tidak menderita diare sebanyak 4 orang balita $(5,5 \%)$, SAB yang dimiliki oleh responden memenuhi syarat sebanyak 31 SAB (42,5\%) dan balita yang menderita diare sebanyak 12 orang balita $(16,4 \%)$ serta balita yang tidak menderita diare sebanyak 19 orang balita (26\%). Responden yang tidak memiliki SAB sebanyak 31 responden, diantaranya terdapat 27 orang balita yang menderita diare (37\%) dan 4 orang balita yang tidak menderita diare (5,5\%). Distribusi kualitas fisik air yang dimiliki oleh responden dengan kejadian diare pada balita dapat dilihat pada tabel 3 di bawah ini : 
Tabel 3. Hasil Analisis Univariat Kualitas Fisik Air dengan Kejadian Diare Pada Balita di Desa Mala Kecamatan Manganitu Tahun 2015

\begin{tabular}{|c|c|c|c|c|c|c|}
\hline \multirow{2}{*}{$\begin{array}{l}\text { Kualitas } \\
\text { Fisik Air }\end{array}$} & \multicolumn{4}{|c|}{ Kejadian Diare Pada Balita } & \multirow{2}{*}{$\mathbf{N}$} & \multirow{2}{*}{$\%$} \\
\hline & Diare & $\%$ & Tdk Diare & $\%$ & & \\
\hline TMS & 7 & 9.6 & 4 & 5.5 & 11 & 15 \\
\hline MS & 12 & 16.4 & 19 & 26 & 31 & 42.5 \\
\hline Tdk ada SAB & 27 & 37 & 4 & 5.5 & 31 & 42.5 \\
\hline Total & 46 & 63 & 27 & 37 & 73 & 100 \\
\hline
\end{tabular}

Tabel 3 menjelaskan bahwa kualitas fisik air yang tidak memenuhi syarat (air berasa, berwarna/keruh dan berbau) sebanyak 11 SAB (15\%) dan balita yang menderita diare sebanyak 7 orang balita $(9,6 \%)$ dan tidak menderita diare sebanyak 4 orang balita $(5,5 \%)$, kualitas fisik air yang memenuhi syarat (air tidak berasa, tidak berwarna dan tidak berbau) sebanyak 31 SAB (42,5\%) dan balita yang menderita diare sebanyak 12 orang balita $(16,4 \%)$ serta balita yang tidak menderita diare sebanyak 19 orang balita (26\%). Responden yang tidak memiliki SAB sebanyak 31 responden, diantaranya terdapat 27 orang balita yang menderita diare (37\%) dan 4 orang balita yang tidak menderita diare $(5,5 \%)$.

2) Penyediaan Jamban dengan Kejadian Diare pada Balita

Hasil pengolahan data unutk penyediaan jamban keluarga sebagian besar responden memiliki jamban keluarga sebesar 43 responden $(59,9 \%)$ dan balita yang menderita diare sebanyak 21 orang balita $(28,8 \%)$, balita yang tidak menderita diare sebanyak 22 orang balita $(30,1 \%)$. Responden yang tidak memiliki jamban sebanyak 30 responden $(41,1 \%)$ dan balita yang menderita diare sebanyak 25 orang balita $(34,2 \%)$, balita yang tidak menderita diare sebanyak 5 orang balita $(6,8 \%)$. Untuk lebih jelasnya dapat dilihat pada tabel 4 di bawah ini :

Tabel 4. Hasil Analisis Univariat Penyediaan Jamban Keluarga dengan Kejadian Diare Pada Balita di Desa Mala Tahun 2015

\begin{tabular}{|c|c|c|c|c|c|c|}
\hline \multirow{2}{*}{$\begin{array}{c}\text { Kepemilikan Jamban } \\
\text { Keluarga }\end{array}$} & \multicolumn{4}{|c|}{ Kejadian Diare Pada Balita } & \multirow{2}{*}{$\mathrm{N}$} & \multirow{2}{*}{$\%$} \\
\hline & Diare & $\%$ & Tdk Diare & $\%$ & & \\
\hline Tidak Ada Jamban & 22 & 30,1 & 3 & 4,1 & 25 & 34,2 \\
\hline Ada Jamban & 24 & 32,9 & 24 & 32,9 & 48 & 65,8 \\
\hline Total & 46 & 63 & 27 & 36.9 & 73 & 100 \\
\hline
\end{tabular}

Distribusi jarak jamban keluarga dengan sarana air berisih dengan kejadian diare pada balita dapat dilihat pada tabel 5 di bawah ini : 
Tabel 5. Hasil Analisis Univariat Jarak Jamban Keluarga dengan SAB dengan Kejadian Diare Pada Balita di Desa Mala Tahun 2015

\begin{tabular}{|c|c|c|c|c|c|c|}
\hline \multirow{2}{*}{ Jarak jamban } & \multicolumn{4}{|c|}{ Kejadian Diare Pada Balita } & \multirow{2}{*}{ Total } & \multirow{2}{*}{$\%$} \\
\hline & Diare & $\%$ & Tdk Diare & $\%$ & & \\
\hline TMS & 12 & 16.4 & 7 & 9.6 & 19 & 26 \\
\hline MS & 12 & 16.4 & 17 & 23.3 & 29 & 39.7 \\
\hline Tidak ada jamban & 22 & 30.1 & 3 & 4.1 & 25 & 34.3 \\
\hline Total & 46 & 62.9 & 27 & 37 & 73 & 100 \\
\hline
\end{tabular}

Tabel 5 menjelaskan bahwa jarak jamban dengan SAB yang tidak memenuhi syarat sebanyak 19 jamban (26\%) dan balita yang menderita diare sebanyak 12 orang $(16,4 \%)$, balita yang tidak menderita diare sebanyak 7 otang balita $(9,6 \%)$, jarak jamban yang tidak memenuhi syarat dengan SAB sebanyak 29 jamban $(39,7 \%)$ balita yang menderita diare sebanyak 12 orang $(16,4 \%)$ dan balita yang tidak menderita diare sebanyak 17 orang balita (23,3\%). Responden yang tidak memiliki jamban sebanyak 25 reponden (34,2\%), balita yang menderita diare sebanyak 22 orang balita $(30,1 \%)$ dan balita yang tidak menderita diare sebanyak 3 orang $(4,1 \%)$. Distribusi jamban keluarga yang memiliki tangky septic dengan kejadian diare pada balita dapat dilihat pada tabel 6 di bawah ini :

Tabel 6. Hasil Analisis Univariat Jamban Keluarga Yang Memiliki Tangky Spetik dengan Kejadian Diare Pada Balita di Desa Mala Kecamatan Manganitu Tahun 2015

\begin{tabular}{ccccccc}
\hline \multirow{2}{*}{ Tangky Septic } & \multicolumn{9}{c}{ Kejadian Diare Pada Balita } & \multirow{2}{*}{ Total } & \multirow{2}{*}{$\%$} \\
\cline { 2 - 5 } & Diare & $\%$ & Tdk Diare & $\%$ & & \\
\hline Tidak ada & 12 & 16,4 & 7 & 9.6 & 19 & 26 \\
Ada tangky septic & 12 & 16.4 & 17 & 23.3 & 29 & 39.7 \\
Tidak ada jamban & 22 & 30,1 & 3 & 4.1 & 25 & 34,2 \\
\hline Total & $\mathbf{4 6}$ & $\mathbf{6 3}$ & $\mathbf{2 7}$ & $\mathbf{3 7}$ & $\mathbf{7 3}$ & $\mathbf{1 0 0}$ \\
\hline
\end{tabular}

Tabel 6 menjelaskan bahwa jamban keluarga yang tidak memiliki tangky septic sebanyak 19 jamban (26\%) dan balita yang menderita diare sebanyak 12 orang $(16,4 \%)$, balita yang tidak menderita diare sebanyak 7 otang balita $(9,6 \%)$, jamban yang memiliki tangky septic sebanyak 29 jamban (39,7\%) balita yang menderita diare sebanyak 12 orang $(16,4 \%)$ dan balita yang tidak menderita diare sebanyak 17 orang balita $(23,3 \%)$. Responden yang tidak memiliki jamban sebanyak 25 reponden $(34,2 \%)$, balita yang menderita diare sebanyak 22 orang balita $(30,1 \%)$ dan balita yang tidak menderita diare sebanyak 3 orang $(4,1 \%)$.

3) Hasil Analisis Bivariat

Hasil analisis data secara bivariat untuk variabel yang berhubungan dengan kejadian diare pada balita di Desa Mala Kecamatan Manganitu dapat diuraikan sebagai berikut : 
1) Hubungan Penyediaan Sarana Air Bersih dengan Kejadian Diare Pada Balita Berdasarkan hasil analisis data secara bivariat untuk hubungan penyediaan sarana air bersih dapat dilihat pada tabel 7 di bawah ini :

Tabel 7. Hubungan Penyediaan Sarana Air Bersih dengan Kejadian Diare Pada Balita di Desa Mala Kecamatan Manganitu Tahun 2015

\begin{tabular}{|c|c|c|c|c|c|c|c|}
\hline \multirow{2}{*}{$\begin{array}{c}\text { Penyediaan Sarana Air } \\
\text { Bersih (SAB) }\end{array}$} & \multicolumn{4}{|c|}{ Kejadian Diare Pada Balita } & \multirow{2}{*}{$\mathrm{N}$} & \multirow{2}{*}{$\%$} & \multirow{2}{*}{$p$-value } \\
\hline & Diare & $\%$ & Tdk Tiare & $\%$ & & & \\
\hline Tidak ada SAB & 26 & 35.6 & 5 & 6.8 & 31 & 42.5 & \multirow{2}{*}{0,002} \\
\hline Ada SAB & 20 & 27.4 & 22 & 30.1 & 42 & 57.5 & \\
\hline Total & 46 & 63 & 27 & 36.9 & 73 & 100 & \\
\hline
\end{tabular}

Tabel 7 menjelaskan bahwa hasil analisis data secara bivariat dengan menggunakan uji chi square, dimana terdapat hubungan yang bermakna antara penyediaan sarana air bersih dengan kejadian diare pada balita, dengan memperoleh nilai $p=0,002$.

2) Hubungan Penyediaan Jamban dengan Kejadian Diare pada Balita

Berdasarkan hasil analisis data secara bivariat dengan menggunakan uji chi square, dimana terdapat hubungan yang bermakna antara penyediaan jamban dengan kejadian diare pada balita, dengan memperoleh nilai $p=0,001$. Untuk lebih jelasnya hubungan penyediaan jamban keluarga dapat dilihat pada tabel 8 di bawah ini :

Tabel 8. Hubungan Penyediaan Jamban dengan Kejadian Diare Pada Balita di Desa Mala Kecamatan Manganitu Tahun 2015

\begin{tabular}{cccccccc}
\hline Kepemilikan & \multicolumn{9}{c}{ Kejadian Diare Pada Balita } & \multirow{2}{*}{ N } & \multirow{2}{*}{$\%$} & \multirow{2}{*}{ p-value } \\
\cline { 2 - 5 } Jamban Keluarga & Diare & $\%$ & Tdk Diare & $\%$ & & & \\
\hline Tidak Ada Jamban & 25 & 34.2 & 5 & 6.8 & 30 & 41.1 & \multirow{2}{*}{0,001} \\
Ada Jamban & 21 & 28.8 & 22 & 30.1 & 43 & 58.9 & \\
\hline Total & $\mathbf{4 6}$ & $\mathbf{6 3}$ & $\mathbf{2 7}$ & $\mathbf{3 6 . 9}$ & $\mathbf{7 3}$ & $\mathbf{1 0 0}$ & \\
\hline
\end{tabular}

\section{PEMBAHASAN}

1. Hubungan Penyediaan Sarana Air Bersih dengan Kejadian Diare Pada Balita

Hasil analisis data untuk penyediaan sarana air bersih pada responden paling banyak adalah responden memiliki sarana air bersih sebanyak 42 responden $(57,5 \%)$ dan responden yang tidak memiliki sarana air bersih sebanyak 31 responden (42,5\%). Responden yang tidak memiliki sarana air bersih dan balita menderita diare sebanyak 26 orang balita $(35,6 \%)$, balita yang tidak menderita diare sebenyak 5 orang balita $(6,8 \%)$. Responden yang memiliki sarana air bersih dan balita menderita diare sebanyak 20 orang balita $(27,4 \%)$ dan balita yang tidak menderita diare sebanyak 22 orang balita $(30,1 \%)$. 
Hasil pengamatan pada rumah responden yang tidak memiliki sarana air bersih, responden tersebut menggunakan sarana air bersih menumpang di rumah tetangga dengan jenis sarana yaitu sumur gali dan ada responden yang memanfaatkan/ menggunakan MCK umum sebagai sarana air bersih. Jenis sarana air bersih yang dimiliki oleh responden yaitu SGL dan PDAM, dengan kualitas fisik air yang digunakan oleh responden yaitu tidak memenuhi syarat sebanyak 11 sumber air bersih $(15,1 \%)$ dan kualitas fisik air yang memenuhi syarat sebanyak 31 sumber air bersih (42,5\%). Responden yang tidak memeiliki SAB sebanyak 31 responden (42,5\%). Hasil analisis data secara bivariat dengan menggunakan uji chi square, dimana terdapat hubungan yang bermakna antara penyediaan sarana air bersih dengan kejadian diare pada balita, dengan memperoleh nilai $p=0,002$.

Hasil penelitian ini sejalan dengan data dari Kemenkes RI (2015) tentang faktor risiko diare pada bayi dan balita di Indonesia, yaitu terdapat hubungan yang bermakna antara penyediaan dan pemanfaatan sarana air bersih dengan kejadian diare pada bayi dan balita yang memperoleh nilai $p=0,005^{3}$. Penelitian yang sama dilakukan oleh Primona, dkk (2013) yang meneliti tentang faktor-faktor yang berhubungan dengan kejadian diare pada anak usia 0-59 bulan, dengan hasil penelitian yaitu ada hubungan yang bermakna antara penyediaan sarana air bersih dengan kejadian diare pada anak usia 0-59 bulan, yang memperoleh nilai $p=0,0294$.

Sarana air bersih harus memenuhi syarat kesehatan seperti sumur gali harus mempunyai dinding dan bibir sumur, mempunyai saluran pembuangan air limbah, terletak \pm 10 meter dari tempat sampah dan kandang ternak, Jika ditinjau dari sudut ilmu kesehatan masyarakat, penyediaan sumber air bersih harus dapat memenuhi kebutuhan masyarakat karena persediaan air bersih yang terbatas memudahkan timbulnya penyakit di masyarakat. Sumber air bersih dan aman yang diperuntukkan bagi konsumsi manusia harus berasal dari sumber yang bersih dan aman. Batasan-batasan sumber air yang bersih dan aman tersebut, antara lain : 1) Bebas dari kontaminasi kuman atau bibit penyakit, 2) Bebas dari substansi kimia yang berbahaya dan beracun, 3) Tidak berasa dan tidak berbau, 4) Dapat dipergunakan untuk mencukupi kebutuhan domestik dan rumah tangga, 5) Memenuhi standar minimal yang ditentukan oleh WHO atau Departemen Kesehatan RI (Ratnawati, 2006) ${ }^{5}$.

Penyakit yang menyerang manusia dapat ditularkan dan menyebar secara langsung maupun tidak langsung melalui air. Penyakit yang ditularkan melalui air disebut sebagai water borne diseases atau water related diseases. Penelitian yang telah dilakukan oleh Dini dan Rasyid (2013), ada pengaruh antara penyediaan air bersih terhadap kejadian diare pada balita yang memperoleh nilai $p=0,000^{6}$. Penelitian yang sama telah dilakukan oleh Mafazah (2013), yang meneliti tentang ketersediaan sarana sanitasi dasar, personal 
hygiene ibu dan kejadian diare, dengan hasil penelitian yaitu terdapat hubungan antara ketersediaan sarana air bersih dengan kejadian diare, yang memperoleh nilai $p=0,021{ }^{7}$. Penelitian ini didukung oleh penelitian yang telah dilakukan oleh Bintoro (2010) yang meneliti tentang hubungan antara sanitasi lingkungan dengan kejadian diare pada balita, dengan hasil penelitian yaitu ada hubungan yang bermakna antara kepemilikan sarana air bersih yang memperoleh nilai $p=0,009^{8}$.

Penyakit diare merupakan salah satu penyakit berbasis lingkungan, dua faktor yang dominan yang dapat menyebabkan diare yaitu sarana air bersih dan pembuangan tinja. Kedua faktor ini akan berinteraksi bersama dengan perilaku manusia. Apabila faktor lingkungan tidak sehat karena tercemar kuman diare serta berakumulasi dengan perilaku manusia yang tidak sehat, seperti makanan dan minuman maka dapat menimbulkan kejadian diare (Bintoro, 2010) ${ }^{8}$. Masalah kesehatan lingkungan utama yang masih dihadapi oleh negara-negara yang sedang berkembang adalah penyediaan air bersih dan air minum, tempat pembuangan sampah, pembuangan sampah, kondisi rumah dan pembuangan pengelolaan air limbah.

Pengadaan air bersih untuk kepentingan rumah tangga, air minum, mandi dan keperluan lainnya harus memenuhi persyaratan yang telah ditentukan oleh peraturan yang berlaku (Irawan, 2012). Kulitas air meliputi : 1) Kualitas fisik, yang meliputi kekeruhan, suhu, warna, baud an rasa, 2) Kualitas kimia, yang menghubungkan adnya ion-ion, senyawa lainnya yang bersifat racun, 3) Kualitas biologis, yang berhubungan dengan kehadiran mikroorganisme pathogen (penyebab penyakit dan pencemaran serta penghasil toksin ${ }^{9}$. Air bersih yang baik harus sesuai peraturan internasional (WHO dan APHA) ataupun peraturan nasional atau setempat. Kualitas air bersih di Indonesia harus memenuhi persyaratan yang tertuang dalam peraturan Menteri Kesehatan RI No.492/MENKES/PER/IV/2010 dimana setiap komponen yang diperkenankan berada di dalamnya harus sesuai ${ }^{10}$.

Air minum yang ideal seharusnya jernih, tidak berwarna, tidak berasa dan tidak berbau.Air minum juga tidak mengandung kuman patogen dan segala mahkluk yang membahayakan kesehatan manusia, tidak mengandung zat kimia yang dapat mengganggu fungsi tubuh, dapat diterima secara estetis dan tidak merugikan secara ekonomis (Wandansari, 2013) ${ }^{11}$. Standar air minum yang mencakup peraturan yang memberi petunjuk tentang kontaminasi berbagai parameter yang sebaiknya diperbolehkan ada dalam air minum. Standar ini berbeda antara satu negara dengan negara yang lain tergantung pada social kultural termasuk kemajuan teknologinya. Standar suatu negara seharusnya layak bagai keadaan sosial ekonomi dan budaya setempat. untuk negara berkembang seperti indonesia, perlu didapat cara-cara pengolahan air yang relatif murah sehingga kualitas air yang dikonsumsi masyarakat 
dapat dikatakan baik dan memenuhi syarat. Parameter yang disyaratkan meliputi; Parameter fisik, kimiawi, biologis dan radiologist (WHO, 2010) ${ }^{12}$.

Ketersediaan sarana air bersih yang tidak memenuhi syarat akan berdampak kurang baik untuk kesehatan, sedangkan penularan diare dapat terjadi melalui air yang digunakan untuk keperluan sehari-hari. Menyadari pentingnya air bagi manusia maka penggunaan air yang tidak memenuhi kriteria standar kualitas sesuai peruntukkannya dapat menimbulkan gangguan kesehatan (Taosu dan Azizah, 2013) ${ }^{13}$. Masih adanya responden yang menderita diare walaupun telah memiliki sarana ketersediaan air bersih di dalam rumahnya disebabkan oleh adanya sumur gali yang dijadikan sebagai sumber air bersih yang tidak memenuhi syarat, dimana masih ada sumur gali yang tidak mempunyai bibir sumur, ada keretakkan pada dinding sumur yang bisa menyebabkan rembesan yang bisa masuk ke dalam sumur, ada sumur yang jarak sumurnya hanya 2 3 meter dari tangki septic jamban, serta adanya sumber pencemaran lain (tempat sampah dan kandang ternak) yang berada dekat dengan sumur gali, hal ini yang diduga bisa menjadi masuknya bahan-bahan pathogen ke dalam air sumur.

\section{Hubungan Penyediaan Jamban dengan Kejadian Diare Pada Balita}

Berdasarkan hasil pengolahan dan analisis data bahwa sebagian besar responden memiliki jamban keluarga sebesar 48 responden $(65,8 \%)$ dan balita yang menderita diare sebanyak 24 orang balita (32,9\%), balita yang tidak menderita diare sebanyak 24 orang balita $(32,9 \%)$. Responden yang menggunakan sarana umum sebanyak 8 responden (11\%), balita yang menderita diare sebanyak 7 orang balita $(9,6 \%)$ dan balita yang tidak menderita diare sebanyak 1 orang balita $(1,4 \%)$. Responden yang menumpang di rumah tentangg sebanyak 17 responden $(23,2 \%)$, balita yang menderita diare sebanyak 15 orang balita $(20,5 \%)$ dan balita yang tidak menderita diare sebanyak 2 orang balita (2,7\%). Responden yang tidak memiliki jamban sebanyak 25 responden $(34,2 \%)$ dan balita yang menderita diare sebanyak 22 orang balita $(30,1 \%)$, balita yang tidak menderita diare sebanyak 3 orang balita $(4,1 \%)$. Hasil wawancara dengan responden, bahwa responden yang tidak memiliki jamban, jika membuang air besar mereka menumpang pada tetangga dan menggunakan MCK umum yang disediakan oleh pemerintah.

Jarak jamban dengan $S A B$ yang tidak memenuhi syarat yaitu jarak jamban kurang 10 meter sebanyak 19 jamban (26\%) dan jarak jamban yang memenuhi syarat (> 10 meter) sebanyak 29 jamban (39,7\%). Bagi responden yang memiliki jamban, masih ditemukan jamban yang tidak memenuhi syarat seperti jamban tidak mempunyai saptic tank terdapat 19 jamban (26\%) dan jamban yang mempunyai tangky septic sebanyak 29 jamban (39,7\%). Apabila hal ini tidak dperhatikan oleh pemilik sarana (jamban keluarga) maka tidak menutup kemungkinan akan menjadi sumber penularan penyakit, 
seperti rembesan pembuangan dari jamban akan mencemari sumur gali yang dimanfaatkan oleh setiap keluarga sebagai sumber air bersih dan air minum.

Berdasarkan hasil analisis data secara bivariat dengan menggunakan uji chi square, dimana terdapat hubungan yang bermakna antara penyediaan jamban dengan kejadian diare pada balita, dengan memperoleh nilai $p=0,001$. Hasil penelitian ini sejalan dengan penelitian yang telah dilakukan oleh Dini dan Rasyid (2013) yang meneliti tentang pengaruh akses penyediaan air bersih terhadap kejadian diare pada balita, dengan hasil penelitian yaitu ada hubungan yang bermakna antara penyediaan sarana jamban keluarga dengan kejadian diare pada balita, yang memperoleh nilai $p=$ 0,0006 . Penelitian yang sama yang telah dilakukan oleh Bintoro (2010) dengan hasil penelitian yaitu ada hubungan yang bermakna antara tidak tersedianya jamban keluarga dengan kejadian diare pada balita, yang memperoleh nili $p=0,0029{ }^{8}$. Penelitian yang telah dilakukan oleh Santoso, dkk (2013) yang meneliti tentang pengaruh perilaku keluarga terhadap penggunaan jamban, dengan hasil penelitian yaitu ada pengaruh antara perilaku keluarga terhadap penggunaan jamban dengan kejadian diare pada balita yang memperoleh nilai $p=0,000^{14}$.

Beberapa penelitian tersebut yang telah membuktikan bahwa ada hubungan yang bermakna antara tidak tersedianya sarana jamban keluarga dengan kejadian diare pada balita, oleh karena itu kotoran manusia harus dikelola dengan baik disuatu tempat tertentu atau di jamban yang sehat. Tujuannya adalah untuk mengurangi kontaminasi tinja terhadap lingkungan. Penggunaan jamban dibeberapa negara membuktikan bahwa upaya penggunaan jamban mempunyai dampak yang sangat besar dalam penurunan terhadap risiko penyakit diare. Keluarga yang tidak mempunyai jamban harus membuat serta menggunakan jamban tersebut sesuai dengan fungsinya. Pembuangan tinja yang memenuhi syarat kesehatan yaitu tidak mengotori permukaan tanah di sekitarnya, tidak mengotori air dalam tanah dan kotoran tidak boleh terbuka sehingga dapat dipakai sebagai tempat berkembang biaknya vektor penyakit.

Dari hasir survey dirumah responden, masih ditemukannya jamban keluarga yang tidak memenuhi syarat, yaitu jamban tidak mempunyai tangki septic dimana lubang pembuangan tinja hanya terbuat dari galian tanah yang tidak diplester/tidak dibeton, jarak jamban yang berdekatan dengan air sumur gali. Jenis jamban yang tidak memenuhi syarat yaitu jenis jamban tanpa tangki septic, dan rumah yang tidak memiliki jamban sehingga bila buang air besar mereka membuang air besar di sungai, menumpang pada tetangga dan memanfaatkan MCK umum yang disediakan oleh pemerintah.

Hasil penelitian yang telah dilakukan oleh Mokoginta (2013) yang meneliti tentang faktor-faktor yang berhubungan dengan kejadian diare pada anak usia 6-24 bulan, 
dengan hasil penelitian yaitu ada hubungan yang bermakna antara tidak tersedianya jamban keluarga dengan kejadian diare pada anak usia 6-24 bulan, yang memperoleh nilai $p=0,046^{15}$. Penelitian ini sejalan dengan penelitian yang telah dilakukan oleh Pebriani, dkk (2012) yang meneliti tentang faktor-faktor yang berhubungan dengan penggunaan jamban keluarga dengan kejadian diare, dengan hasil penelitian yaitu ada hubungan yang bermakna antara kondisi jamban dengan kejadian diare. Kondisi jamban yang tidak memenuhi syarat sangat berhubungan dengan kejadian diare ${ }^{16}$.

Penyakit diare dapat ditularkan melalui kotoran manusia, semua orang dalam keluarga harus menggunakan jamban dan jamban harus dalam keadaan bersih agar terhindar dari serangga yang dapat menularkan atau memindahkan penyakit pada makanan. Penggunaan jamban yang sehat dan menjaga kebersihan jamban dapat menurunkan risiko penyakit diare, adapun persyaratan jamban yang sehat yaitu : 1). Tidak mengotori permukaan tanah disekitar jamban, 2). Tidak mencemari air permukaan disekitar jamban, 3). Tidak mengotori air tanah, 4). Tidak menjadi tempat berkembang biaknya serangga dan binatang pembawa bibit penyakit, 5). Tidak menimbulkan bau (Kemenkes RI, 2013) ${ }^{17}$.

\section{SIMPULAN DAN SARAN}

Ada hubungan yang bermakna antara penyediaan air bersih dengan kejadian diare pada balita di Desa Mala Kecamatan Manganitu dan ada hubungan yang bermakna antara jamban keluarga dengan kejadian diare pada balita di Desa Mala Kecamatan Manganitu. Saran Bagi masyarakat yang tidak mempunyai sarana air bersih dan jamban keluarga agar membuat atau membangun sarana air bersih dan jamban keluarga dan Perlunya peranan dan dukungan petugas kesehatan dalam usaha pencegahan penyakit diare yang di tularkan lewat lingkungan, petugas selalu melakukan pengamatan dan pengawasan untuk menjaga penyebaran penyakit berbasis lingkungan seperti penyakit diare.

\section{DAFTAR PUSTAKA}

1. WHO, 2010. Water Sanitation and Helath Common Water, Available from : http://www.searo.who.int. com(cited 2010, $11^{\text {th }}$ Desember)

2. Dinkes Kabupaten Kepl. Sangihe, 2014. Profil Kesehatan Dinas Kesehatan Kab. Kepl. Sangihe. Tahuna

3. Kemenkes RI, 2015. Tatalaksana Diare Pada Balita. Dirjen P2PL dan PPM, Jakarta

4. Primona, I. Rasmalia dan Hiswani., 2013. Faktor-Faktor Yang Berhubungan Dengan Kejadian Diare Pada Anak Usia 0 - 59 Bulan di Wilayah Kerja Puskesmas Simarmata Kecamatan Simanindo Kabupaten Samosir Tahun 2013. Fakultas Kesehatan Masyarakat, Universitas Sumatera Utara. 
5. Ratnawati, Dewi, 2012. Faktor Resiko Kejadian Diare Akut pada Balita di Kabupatem Kulon Progo.

6. Dini F, Macmud R, dan Rasyid R. 2013. Hubungan Faktor Lingkungan Dengan Kejadian Diare balita di Wilayah Kerja Puskesmas Kambang Kecamatan Lengayang Kabupaten Pesisir Selatan. Jurnal FK. Unand.

7. Mafazah, L. 2013. Ketersediaan Saran Sanitasi Dasar, Personal Hygiene Ibu dan Kejadian Diare. Jurnal Kesehatan Masyarakat, Universitas Negeri Semarang.

8. Bintoro, B. R., 2010. Hubungan Antara Sanitasi Lingkungan dengan Kejadian Diare Pada Balita di Kecamatan Jatipuro Kabupaten Karanganyar. Fakultas IImu Kesehatan, Universitas Muhammadiyah Surakarta.

9. Irawan A.Y, (2012). Hubungan Antara Aspek Kesehatan Lingkungan Dalam PHBS Rumah Tangga Dengan Kejadian Penyakit Diare di Kecamatan Karangreja Tahun 2012. Unnes Journal of Public Health, Semarang.

10. Ditjen Pengendalian Penyakit dan Penyehatan Lingkungan, 2010. Peraturan Menteri Kesehatan RI. No. 492/MENKES /PER/ IV/2010 tentang Persyaratan Kualitas Air Minum. Kemenkes RI, Jakarta

11. Wandansari A.P. (2013). Kualitas Sumber Air Minum dan Pemanfaatan Jamban Keluarga dengan Kejadian Diare. Unnes Journal of Public Health, Semarang

12. WHO, (2010). Water Sanitation and Helath Common Water, Available from : http://www.searo.who.int.com(cited 2017, $11^{\text {th }}$ Desember)

13. Taosu S.A dan Azizah R, (2013). Hubungan Sanitasi Dasar Rumah dan Perilaku Ibu Rumah Tangga Dengan Kejadian Diare Pada Balita di Desa Bena Nusa Tenggara Timur. Departemen Kesehatan Lingkungan FKM Universitas Airlangga. Surabaya

14. Santoso E. N, Rambi, E.V dan Katiandagho D, (2013). Analisis Faktor Risiko Penyakit Berbasis Lingkungan di Kota Manado. Riset Pembinaan Tenaga Kesehatan, Jurusan Kesehatan Lingkungan Poltekkes Kemenkes Manado

15. Mokoginta J. (2013). Analisis Hubungan Faktor-Faktor Lingkungan Dengan Kejadian Diare Pada balita Di Wilayah Kerja Puskesmas Sario Kota Manado. Program Pascasrajana Universitas Sam Ratulangi. Manado

16. Pebriani R.A, Dharma S. dan Naria E., 2012. Faktor-Faktor Yang Berhubungan Dengan Penggunaan Jamban Keluarga dan kejadian Diare di Desa Tualang Sembilar Kecamatan Bambel Kab. Aceh Tenggara Tahun 2012. Departemen Kesehatan Lingkungan, Universitas Sumatera Utara

17. Kemenkes RI, 2013. Riset Kesehatan Dasar, 2013. Badan Penelitian dan Pengembangan Kesehatan, Kemenkes RI. Jakarta 